\title{
THERMO-CATALYTIC PROCESSING OF POLYMER WASTE OVER CATALYSTS ON THE BASIS OF NATURAL ZEOLITE FROM THE TAYZHUZGEN FIELD (KAZAKHSTAN) MODIFIED BY MOLYBDENUM
}

\author{
Y. A. Aubakirov ${ }^{1}$, L. R. Sassykova ${ }^{*}$, Zh. Kh. Tashmukhambetova ${ }^{1}$, \\ F. Zh. Akhmetova ${ }^{1}$, S. Sendilvelan ${ }^{2}$, K.O. Sharipov', \\ Sh. N. Kubekova ${ }^{4}$, A.A. Batyrbayeva ${ }^{1}$, R.N. Azhigulova ${ }^{1}$, \\ R. G. Ryskaliyeva ${ }^{1}$, A.K. Zhussupova ${ }^{1}$ and T. S. Abildin ${ }^{1}$ \\ ${ }^{1}$ Al-Farabi Kazakh National University, 71, al-Farabi ave., Almaty-050040, Kazakhstan, \\ ${ }^{2}$ Department of Mechanical Engineering, Dr.M.G.R.Educational and Research Institute, \\ University, Chennai-600095, Tamilnadu, India, \\ ${ }^{3}$ Asfendiyarov Kazakh National Medical University, Almaty-050000, Kazakhstan, \\ ${ }^{4}$ Satbayev University, Almaty-050013, Kazakhstan, Kazakh National Research Technical \\ University After K.I.Satpayev, Almaty, Kazakhstan. \\ *E-mail: larissa.rav@mail.ru
}

\begin{abstract}
The paper describes the hydrogenating thermo-catalytic processing of plastic waste on the developed new catalysts based on natural zeolite from the Tayzuzgen deposit (Kazakhstan), with molybdenum additives (on the base of $\left.\left(\mathrm{NH}_{4}\right)_{6} \mathrm{Mo}_{2} \mathrm{O}_{24} \cdot 4 \mathrm{H}_{2} \mathrm{O}\right)$. Fuel oil from the Kumkol oil field (Kazakhstan), characterized by a high content of paraffin hydrocarbons, high pour point and low sulfur content was used as additional raw material, source of hydrogen and a paste generator. Analysis of the reaction products shows that the process proceeds mainly with the formation of aromatic compounds, alkanes, cycloalkanes, alkenes and cycloalkenes, isoalkanes. According to the composition of hydrocarbon fractions with a boiling point of up to $180^{\circ} \mathrm{C}$ on a catalyst with $0.5 \% \mathrm{Mo}$, the content of saturated hydrocarbons was relatively high $(20.92 \%)$, for catalysts containing $1.0 \%$ Mo, there was a high content of aromatic hydrocarbons $(21 \%$ and $45 \%)$. The highest yield of the gasoline and diesel fractions is observed at a concentration of Mo (VI) $-0.5 \%$. The total yield of liquid distillate obtained by thermal catalytic hydrogenation processing of plastic waste amounted to $34.59 \%$ wt. The optimal conditions for the process of hydrogenation of thermal catalytic processing of polymer waste into motor fuels were determined. The synthesized catalysts showed their activity and selectivity and can be used in the process of hydrogenation of thermal catalytic processing of polymer waste into motor fuels.
\end{abstract}

Keywords: Polymer Wastes, Natural Tayzhuzgen Zeolite, Hydrogenation Thermocatalytic Recycling, Molybdenum, Kumkol Oil Field, Motor Fuels

(C) RASĀYAN. All rights reserved

\section{INTRODUCTION}

At present, the state of research in the field of hydrogenation catalytic processing of waste solid fuels and polymeric materials determines the need for additional searches to expand the range of technologies and catalysts. ${ }^{1-3}$ A promising direction in this area is the search for new catalysts based on available natural zeolites of the Republic of Kazakhstan, modified by various additives. ${ }^{4,5}$

Plastic materials are the basis for the innovation of many products in various sectors, such as construction, health, electronics and others. The increase in the use of polymeric materials in all areas of industry and in everyday life, as well as the reduction of their service life, led to one of the most important problems faced by world civilization - the problem of environmental pollution by polymeric wastes. ${ }^{6-9}$ Such waste

Rasayan J. Chem., 12(4), 1701-1709(2019)

http://dx.doi.org/10.31788/RJC.2019.1245435

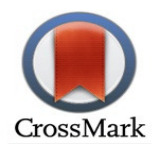


does not decay under natural conditions and when burning emits harmful toxic substances. The solution of this problem is the development of new technologies of processing of industrial wastes and also search for catalysts which will allow solving a problem of fuels shortage. ${ }^{10-13}$

Thermochemical processing is the transformation of high-molecular structures of waste plastics into smaller molecules, that is, from solid polymer to liquid or gas, which are suitable for use as a raw material for the production of new petroleum products and plastics. ${ }^{12-16}$ So, for example, the thermochemical conversion is used for biomass processing, which includes a hydrothermal process, gasification, pyrolysis, hydrolysis into sugar. Of particular note is pyrolysis, the process of thermal depolymerization of biomass in the absence of air or inert conditions at moderate temperatures. By pyrolysis, biomass can be converted into dense energy, ("bio-oil"), which is easy to transport. In addition to liquid products, the process may result in semi-coke, non-condensable gases containing carbon oxides and light hydrocarbons. ${ }^{15-20}$ Plastics waste is a cheap hydrogen resource. Most plastics have higher (H/C) efficiency indicators than biomass. ${ }^{6-9,19-22}$

Classical catalysts used for hydrocracking processes in refining fields are mainly used for the hydrocracking of polymer wastes. These catalysts consist of transition metals ( $\mathrm{Pt}, \mathrm{Ni}, \mathrm{Mo}, \mathrm{Fe}$ ) supported on solid acids (aluminum oxide, amorphous aluminosilicate, zeolites, etc.).

In the course of thermocatalytic hydrogenation processing of polymeric waste, the hydrocarbon fractions close on the structure to motor fuels can be produced. In general, it will allow to involve secondary raw material resources in processing, to fill up the market with additional commodity fuel materials and to affect favorably state of environment. ${ }^{21-27}$ Today the greatest distribution was gained by the technology of recycling, that is secondary processing of plastic. It allows not only to utilize industry waste, but also to keep resources of the environment. One of such ways is thermocatalytic hydrogenation processing of polymeric waste for the purpose of producing liquid motor fuels. ${ }^{28-30}$

In this research for the first time, new active and selective catalysts based on a natural zeolite from the Tayzhuzgen deposit (Kazakhstan) modified with Mo (VI) salt have been developed and have been used for hydrogenation thermocatalytic processing of plastic waste. The surface and structural properties of catalysts synthesized were shown.

\section{EXPERIMENTAL}

Fuel oil from Kumkol oil field (Kazakhstan) was used as additional raw material, source of hydrogen and paste-forming agent. This fuel oil is characterized by a high content of paraffin hydrocarbons, a high pour point and a low sulfur content. Some Physico-chemical characteristics of the heavy fraction of oil from the Kumkol field, previously defined in the works, ${ }^{31-33}$ are listed in the Table-1.

Table-1: Kumkol Oil Field Characteristics

\begin{tabular}{l|c|c}
\hline No & Indicator & Value \\
\hline 1 & Density, $\mathrm{g} / \mathrm{cm}^{3}$ & 0.83 \\
\hline 2 & Viscosity at $20^{\circ} \mathrm{C}, \mathrm{mm}^{2} / \mathrm{s}$ & 9.69 \\
\hline \multicolumn{3}{|c}{ Content, $\%$ by wt. } \\
\hline 3 & Paraffins & 14.78 \\
\hline 4 & Asphaltenes & 1.52 \\
\hline 5 & \multicolumn{2}{|c}{ Resins (Pitches) } \\
\hline \multicolumn{3}{|c}{ Elemental composition, \% by wt. } \\
\hline 6 & $\mathrm{C}$ & 83.80 \\
\hline 7 & $\mathrm{H}$ & 11.20 \\
\hline 8 & $\mathrm{~N}$ & 0.80 \\
\hline 9 & $\mathrm{~S}$ & 1.80 \\
\hline 10 & $\mathrm{O}$ & 2.40 \\
\hline 11 & V content & $2.58 \cdot 10^{-4}$ \\
\hline 12 & Ni content & $2.50 \cdot 10^{-4}$ \\
\hline 13 & Cocking ability, $\%$ & 2.80 \\
\hline
\end{tabular}

As follows from the Table-1, asphaltene-resin-paraffin deposits contain 6-10\% of paraffins, $10-16 \%$ tar, $52-55 \%$ asphaltenes and $20-28 \%$ oils and mechanical impurities. These deposits are characterized by a melting point of $82-85^{\circ} \mathrm{C}$. 
For the process of hydrogenation processing of waste of plastic, catalysts were synthesized. For catalysts preparation was applied the natural heylandite-clinoptilolite zeolites of the Tayzhuzgen field (Kazakhstan) subjected to acid-free activation and calcinating modified by the salt of molybdenum (VI) Mo (VI)/zeolite of different concentration. The deposit of zeolites "Tayzhuzgen" is located in Tarbagatai district of the East Kazakhstan region (Kazakhstan).

Process of catalytic hydrogenation processing of waste of plastic was carried out on the installation working in the mode of periodic action under pressure from 0.5 to $0.6 \mathrm{MPa}$ and at a temperature of $450^{\circ} \mathrm{C}$ with continuous stirring. The pressure was created by transmission through nitrogen installation. Wide range of change of pressure in a system was caused by the release of hydrogen which source was fuel oil. The feedstock (plastic) was pre-crushed to a crumb state with a particle size of 2-6 $\mathrm{mm}$. The prepared mixture of a catalyst, a paste former and plastic has been loaded into the reactor. Then the unit was flushed with nitrogen and the required pressure and temperature were established. The process was carried out in a previously optimized mode using the example of hydrogenation catalytic processing of plastics $\left(\mathrm{T}=450^{\circ} \mathrm{C}, 7.0 \mathrm{~g}\right.$ of fuel oil, $7.0 \mathrm{~g}$ of plastic, $0.42 \mathrm{~g}$ of catalyst, contact time - 15 min.).Experimental work in this study differs from previous studies in that the study of the process was first carried out in a continuous catalytic reactor operating under pressure in the cycle-stirring modethermo catalysis and hydrogenation of the raw material $\rightarrow$ a direct distillation of liquid distillate and removal of gases. The process was carried out without the stage of discharging the liquid product and its further distillation.

Liquid products of thermal catalytic hydrogenation processing of polymer wastes in the presence of a new composite catalyst were divided into fractions with boiling points: up to $180^{\circ} \mathrm{C}, 180-250^{\circ} \mathrm{C}$ and 250 $320^{\circ} \mathrm{C}$. After the process, the product was separated into fractions at $0-180^{\circ} \mathrm{C}, 180-250^{\circ} \mathrm{C}$ and $250-320^{\circ} \mathrm{C}$ boiling point. Chromatographic analysis of fuel distillates was performed on an Agilent Technologies HP 5890 gas chromatograph with a $5975 \mathrm{C}$ mass spectrometry detector. ${ }^{4,531-35}$ For the analysis, the mobile phase of grade A, chromatographic column HP $=5 \mathrm{~S}, 30 \mathrm{~m}$ long, $0.25 \mathrm{~mm}$ thick, the adsorbent thickness inside the capillary $0.5 \mu \mathrm{m}$, were used. Chromatograms and mass spectra were processed using MSD ChemStation E 02.00.493. To identify substances by mass spectra, a NIST-8 mass spectra database was used.

The qualitative and quantitative composition of the starting and compositional catalysts was determined by X-ray fluorescence analysis. The analysis data are the same as the energy dispersion spectroscopy data. The morphology of the catalyst samples was studied using a JEOLJSM 6460LV scanning electron microscope, Quanta 200i 3D electron microscope (FEI Company, USA). Determination of the chemical composition of the samples of catalysts was carried out by the method of energy dispersive spectroscopy (EDS) using an attachment to the INCA microscope at two points of each sample. The microanalytical system is equipped with a microscope with an energy-efficient X-ray analyzer (EDAX). The range of detected elements is $\mathrm{B} \div \mathrm{U}$. Energy tolerance is $132 \mathrm{EV}(\mathrm{Mn} \mathrm{K} \alpha)$. Range - up to $+1,000^{\circ} \mathrm{C}$ heating module. The determination of the IR spectra was performed on a UR-20 spectrometer in the region of 400-4,400 $\mathrm{cm}^{-1}$. Using the X-ray method on the Shimadzu FTIR 8300 unit, the presence of acid sites in the catalysts has been determined by the shift of the $\mathrm{CO}$ line oscillations. Electronic spectra of diffuse reflectance (ESDO) were taken with a spectrophotometer UV-2501 PC company "Shimadzu”.

\section{RESULTS AND DISCUSSION}

Samples of the original and activated zeolite were studied using IR spectroscopy (Figure-1, Figure-2). It was found that the spectrum of the initial natural zeolite contains adsorption bands of $2,360.81 \mathrm{~cm}^{-1}$ and $1031.54 \mathrm{~cm}^{-1}$, Lewis acid sites. For the spectrum of activated zeolite, bands in the region of $1,056.98 \mathrm{~cm}^{-1}$ and $652.80 \mathrm{~cm}^{-1}$, corresponding to the Bronsted acid centers, were noticed.

By the X-ray method on the Shimadzu FTIR 8300 of an activated zeolite from the Tayzhuzgen deposit, the presence of acid sites in it has been found. It was established that an insignificant amount of proton and aprotic acid centers is present in its structure due to the shift of the $\mathrm{CO}$ line oscillations, which made it possible to make an assumption about the potential activity of the zeolite for the catalytic splitting of the initial carbon-containing raw material with the predominant formation of a liquid product enriched in short-chain paraffinic, naphthenic and arene hydrocarbons. The spectrum of the sample Fe-Al-Si (Fig.-3) 


\section{RASĀYAN J. Chem.}

Vol. 12 | No. 4 |1701 - 1709| October - December | 2019

contains absorption bands with maxima in the range of $18,500 \mathrm{~cm}^{-1}$ and $21,000 \mathrm{~cm}^{-1}$, which is most likely due to the appearance of dd-transitions of $\mathrm{Fe}^{3+}$ cations in octahedral coordination $\left(\mathrm{Fe}^{3+}{ }_{\mathrm{Oh}}\right)$ stabilized in $\mathrm{Al}$ $\mathrm{Si}$ matrix. In this case, strong absorption can be attributed with high probability to the charge-transfer band of the ligand-metal $\mathrm{Fe}^{3+}{ }_{\text {Oh }}$ cations.

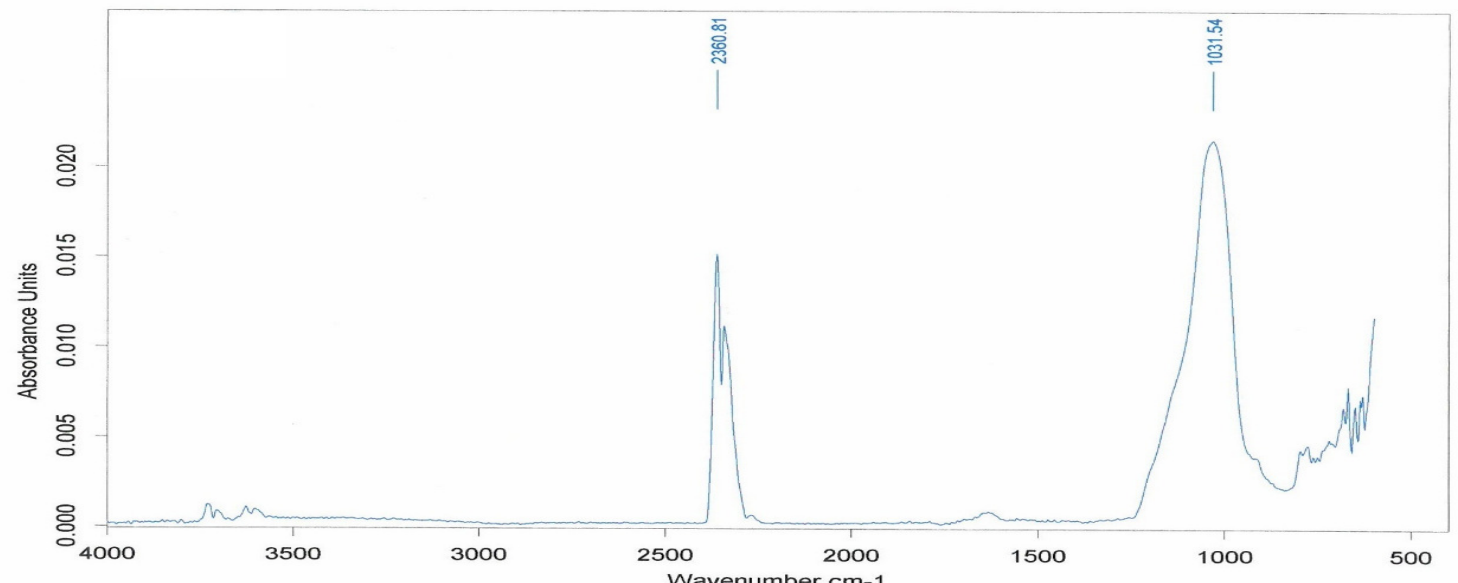

Fig.-1: IR Spectroscopy of the Original Natural Zeolite of the Tayzhuzgen Deposit.

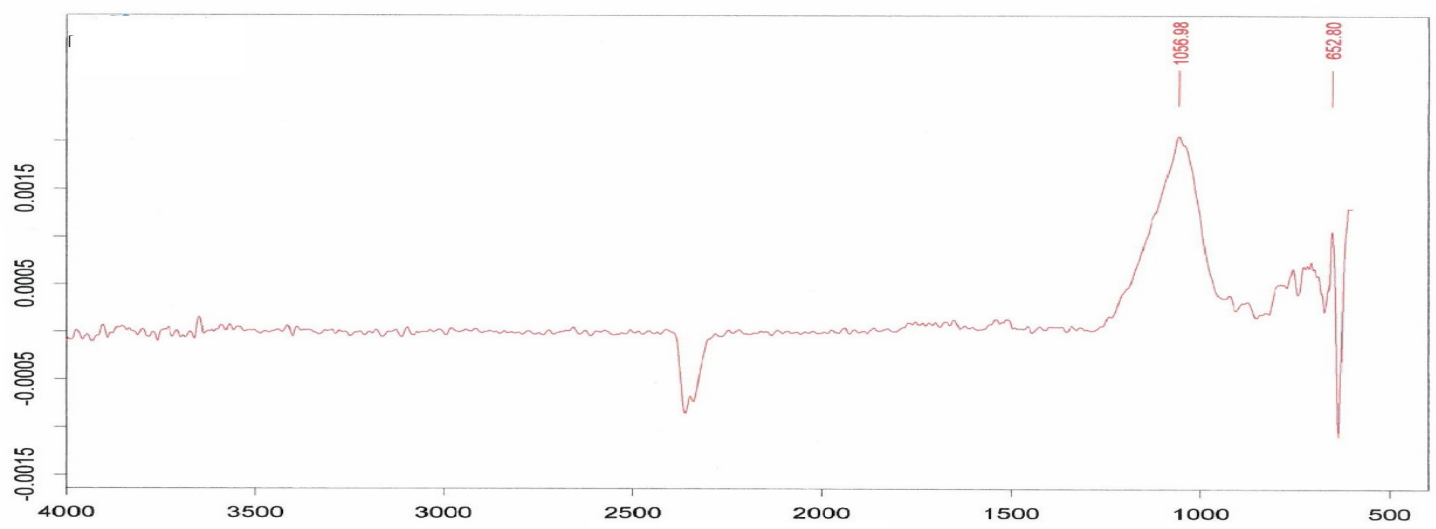

Fig.-2: IR Spectroscopy of Activated Natural Zeolite From the Tayzhuzgen Deposit

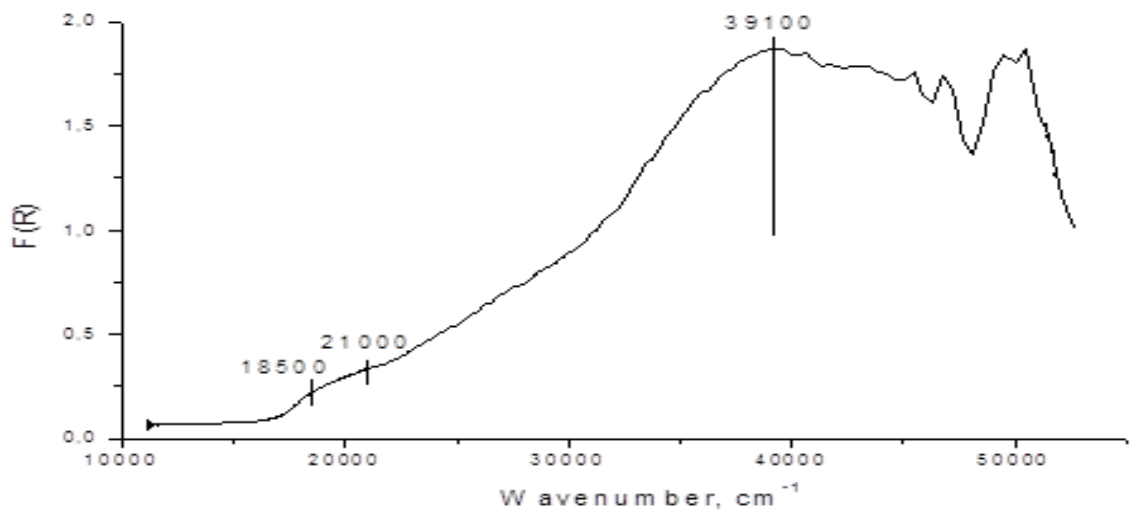

Fig.-3: ESDO Spectra of the Sample Fe-Al-Si (Initial Zeolite)

The elemental composition of the initial zeolite of Tayzhuzgen deposit and activated by Mo was determined by X-ray fluorescent analysis (Table-2). There were revealed eight different components. 
RASĀYAN J. Chem.

Vol. 12 | No. 4 |1701 - 1709| October - December | 2019

Table-2: The Elemental Composition of the Initial Zeolite of the Tayzhuzgen Deposit

\begin{tabular}{c|c|c|c|c|c|c|c|c|c|c|c}
\hline Element & $\mathrm{Fe}$ & $\mathrm{Al}$ & $\mathrm{Si}$ & $\mathrm{Ca}$ & $\mathrm{Cr}$ & $\mathrm{Mn}$ & $\mathrm{Ti}$ & $\mathrm{Ni}$ & $\mathrm{K}$ & $\mathrm{Zn}$ & $\mathrm{Sr}$ \\
\hline Concentration, \% & 14.81 & 19.49 & 46.09 & 5.52 & 0.05 & 0.09 & 0.45 & 0.12 & 12.12 & 0.37 & 0.88 \\
\hline Intensity & 159.14 & 0.34 & 1.97 & 15.86 & 0.36 & 0.94 & 2.37 & 0.99 & 14.87 & 3.67 & 6.79 \\
\hline
\end{tabular}

From the data on the elemental composition of the activated zeolite, the content of silicon and aluminum oxides, determined by weight and atomic percent, is 3.49 and 3.35, which corresponds to the values of this indicator for effective zeolite catalysts for the process of cracking hydrocarbons $\left(\mathrm{SiO}_{2} / \mathrm{Al}_{2} \mathrm{O}_{3}=3-6\right)$. As follows from the analysis of the composition of the activated zeolite of the Tayzhuzgen deposit, during acid treatment in its structure, the content of metals such as Fe, Mn, etc., apparently, according to the EMF spectra, is very small and was not detected by this method. However, the presence of iron compounds in it is proved by the method of IR-spectroscopy (ESDO).

Samples based on the original and acid-free zeolite were investigated by electron microscopy at 10,000x magnification. On the surface of the sample of non-activated zeolite (Fig.-4) and activated zeolite (Fig.-5) finely dispersed friable formations of the porous structure are observed.

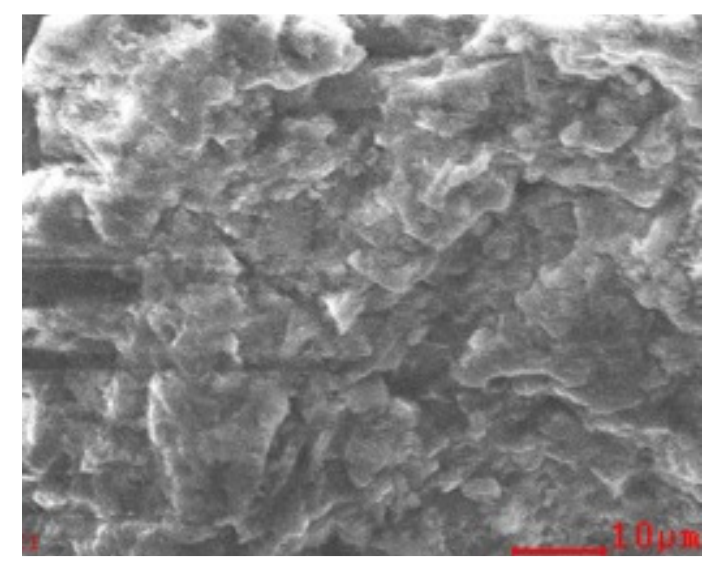

\begin{tabular}{l|l|l}
\hline Element & $\mathrm{Wt} \%$ & $\mathrm{At} \%$ \\
\hline $\mathrm{CK}$ & 4.91 & 8.61 \\
\hline $\mathrm{OK}$ & 39.93 & 52.64 \\
\hline $\mathrm{NaK}$ & 1.51 & 1.39 \\
\hline $\mathrm{AlK}$ & 9.56 & 7.47 \\
\hline $\mathrm{SiK}$ & 30.98 & 23.26 \\
\hline $\mathrm{KK}$ & 10.42 & 5.62 \\
\hline $\mathrm{FeK}$ & 2.69 & 1.02 \\
\hline Matrix & Correction & $\mathrm{ZAF}$ \\
& & \\
& & \\
& & \\
\hline
\end{tabular}

Fig.-4: SEM-Image of a Non-Activated Tayzhuzgen Zeolite.

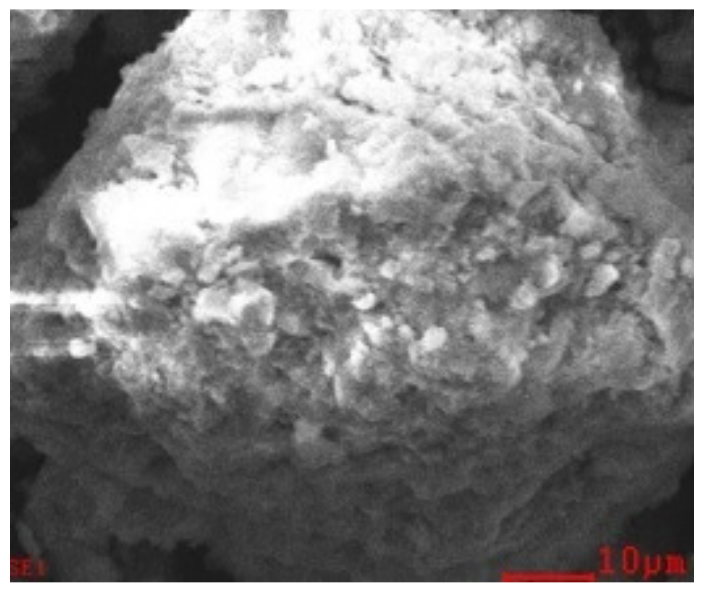

\begin{tabular}{l|l|l}
\hline Element & $\mathrm{Wt} \%$ & $\mathrm{At} \%$ \\
\hline $\mathrm{CK}$ & 7.34 & 12.28 \\
\hline $\mathrm{OK}$ & 43.41 & 54.53 \\
\hline $\mathrm{MgK}$ & 0.79 & 0.65 \\
\hline $\mathrm{AlK}$ & 8.67 & 6.46 \\
\hline $\mathrm{SiK}$ & 31.44 & 22.49 \\
\hline $\mathrm{KK}$ & 3.81 & 1.96 \\
\hline FeK & 4.54 & 1.63 \\
\hline Matrix & Correction & ZAF \\
& & \\
& & \\
& & \\
& & \\
\hline
\end{tabular}

Fig.-5: SEM-Image of an Activated Zeolite.

In the catalysts, an approximately equal content of $\mathrm{Si}, \mathrm{Al}, \mathrm{O}$ is also noted, along with metals $\mathrm{K}, \mathrm{Fe}, \mathrm{Mg}$, which differ slightly in percentage. $\mathrm{Na}$ is absent in the sample of the activated zeolite, the $\mathrm{K}$ content is underestimated and the $\mathrm{Mg}$ content is almost not traced, which may be due to the acid-free activation of the zeolite sample by $\mathrm{NH}_{4} \mathrm{Cl}$ solution. Due to this procedure, as a result of ion exchange, alkali and alkaline earth metals $(\mathrm{K}, \mathrm{Na}, \mathrm{Mg})$ in the zeolite composition were partially replaced by the cation $\mathrm{NH}^{4+}$. 
RASĀYAN J. Chem.

Vol. 12 | No. 4 |1701 - 1709| October - December | 2019

Figure-6 shows microelectronic photographs of catalysts $0.5 \%$ Mo (VI)/zeolite at magnifications x 5,000 and $\mathrm{x} 10,000$. With an increase in the resolution of the microscope to 5,000, and 10,000 heterogeneity of the surface morphology of the catalyst on the basis of $0.5 \%$ Mo (VI)/zeolite was found. There were particles up to 1.36 are traced; 1.70 and $6.66 \mu \mathrm{m}$ to 752.0 and $979.1 \mathrm{~nm}$, respectively. In general, the catalyst is a granular formation with a very large scatter of grains in size. Modifying the surface of the activated zeolite leads to a smoothing of the edges of the pores and their heterogeneity in size., $43,36-41$

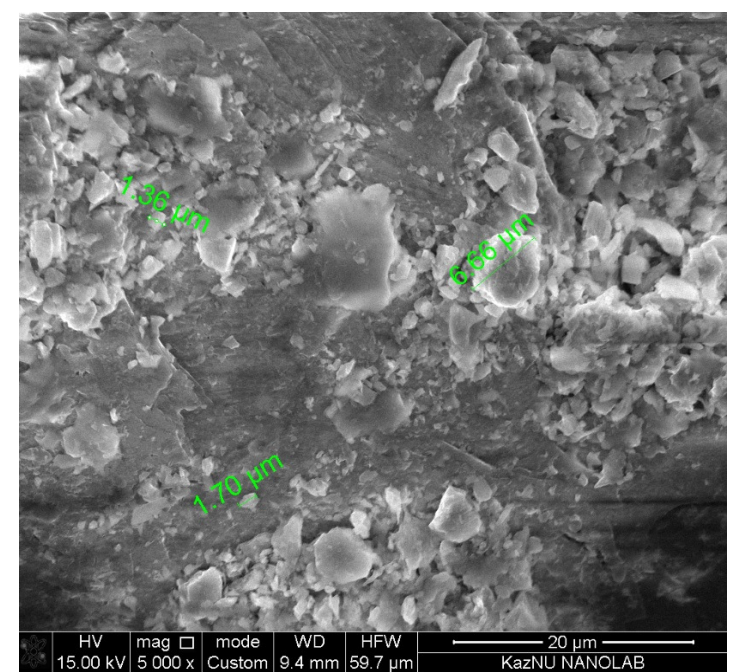

(a)

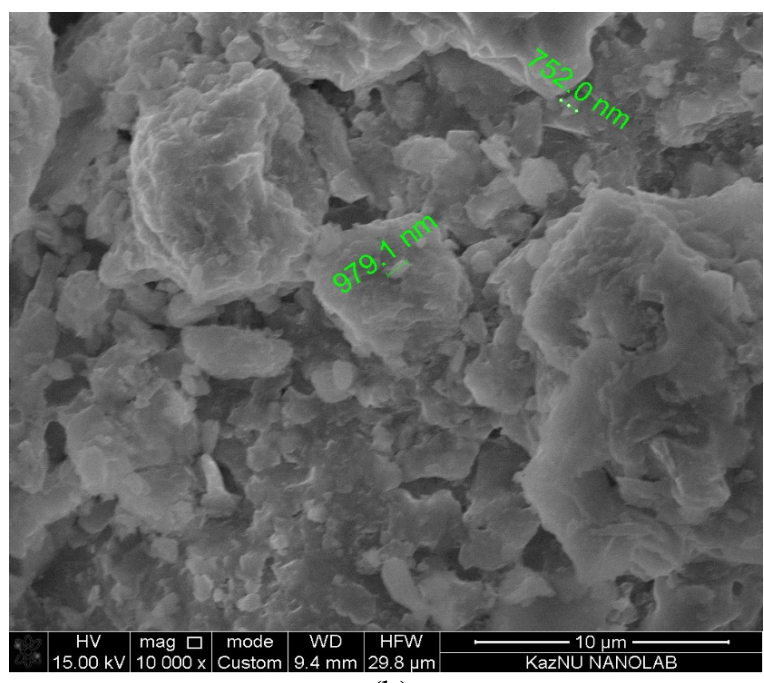

(b)

Fig.-6: Microelectronic Photographs of the Catalyst 0.5\% Mo (VI)/zeolite: (a) x5,000; (b) x10,000

In the catalyst based on $1.0 \%$ Mo (VI)/zeolite with an increase in the resolution of the microscope up to $1,000 \mathrm{x}, 5,000 \mathrm{x}$ and $10,000 \mathrm{x}$, a heterogeneity of the surface morphology was also detected, where larger particles up to 2.12 were traced; 5.11 and 8.01 microns to $1.28 ; 1.34$ and 3.35 microns, respectively. In general, the catalyst is a larger formation of a fairly uniform porous structure.

According to the analysis of thermal catalytic hydrogenation processing of polymer wastes-hydrocarbons, the process proceeds primarily with the formation of aromatic compounds, alkanes, cycloalkanes, alkenes and cycloalkenes, isoalkanes (Table-3).

Table-3: Chemical Composition of Hydrocarbons with a Boiling Point of up to $180^{\circ} \mathrm{C}$ for the Thermal Catalytic Hydrogenation Processing of Polymeric Wastes in the Presence of a Supported Catalyst Based on a Zeolite From the

Tayzhuzgen Deposit with $0.5 \%$ Mo

\begin{tabular}{c|c|c|c}
\hline No & Name of Compounds & Concentration, wt. \% & Retention Time, min. \\
\hline 1 & Hexane & 2.46 & 2.130 \\
\hline 2 & 1,2-dimethyl-trans-cyclopentane & 1.70 & 2.823 \\
\hline 3 & Methylcyclohexane & 2.14 & 3.189 \\
\hline 4 & 2-methylheptane & 1.05 & 3.681 \\
\hline 5 & Toluene & 2.49 & 3.732 \\
\hline 6 & 1-methylcyclohexene & 1.31 & 3.778 \\
\hline 7 & Ethylcyclohexane & 1.12 & 4.688 \\
\hline 8 & Ethylbenzene & 2.39 & 5.129 \\
\hline 9 & p-xylene & 3.47 & 5.260 \\
\hline 10 & Nonen-1 & 1.27 & 5.581 \\
\hline 11 & 1,3-dimethylbenzene & 1.80 & 5.644 \\
\hline 12 & 1-ethyl-2-methylbenzene & 2.85 & 6.759 \\
\hline 13 & 1,2,3-trimethylbenzene & 1.97 & 7.297 \\
\hline 14 & Decane & 8.74 & 7.383 \\
\hline 15 & Undecen-1 & 1.46 & 8.802 \\
\hline 16 & Undecane & 3.60 & 8.962 \\
\hline 17 & Dodecane & 1.89 & 10.456 \\
\hline
\end{tabular}


A comparison of the recycling process on catalysts containing different molybdenum contents - either $0.5 \%$ molybdenum or $1.0 \%$ molybdenum was made (Table-4). On the composition of hydrocarbon fractions with a boiling point of up to $180^{\circ} \mathrm{C}$ on a catalyst with $0.5 \% \mathrm{Mo}$, the content of saturated hydrocarbons was relatively high $(20.92 \%)$, for catalysts containing $1.0 \%$ Mo there was a high content of aromatic hydrocarbons $(21.45 \%)$. In accordance with this, the process went towards the aromatization reaction, cycling and decomposition. ${ }^{4,5,42-47}$

According to the material balance calculated for the process on the Mo (VI)/zeolite catalyst, the highest yield of the gasoline and diesel fractions was observed at a Mo (VI) concentration of $0.5 \%$. The total yield of liquid distillate obtained by thermal catalytic hydrogenation processing of plastic waste was $34.59 \%$ by wt.

Table-4: Results of Catalytic Hydrogenation Processing of Waste Plastics and Fuel Oil From Kumkol Oil Field (Kazakhstan) as An Additional Raw Material Over Catalysts on the Base of Mo-Containing Tayzhuzgen Zeolite

\begin{tabular}{c|c|c|c|c|c|c}
\hline Catalyst & $\begin{array}{c}\mathrm{V} \\
(\mathrm{gas}), \\
\mathrm{ml}\end{array}$ & $\begin{array}{c}\mathrm{M} \\
\left(0-180^{\circ} \mathrm{C}\right), \mathrm{g}\end{array}$ & $\begin{array}{c}\mathrm{M} \\
\left(180-250^{\circ} \mathrm{C}\right), \mathrm{g}\end{array}$ & $\begin{array}{c}\mathrm{M} \\
\left(250-320^{\circ} \mathrm{C}\right), \\
\mathrm{g}\end{array}$ & $\begin{array}{c}\mathrm{M} \text { (Residue), } \\
\mathrm{g}\end{array}$ & $\begin{array}{c}\text { The yield of } \\
\text { Liquid } \\
\text { Distillate, } \%\end{array}$ \\
\hline $\begin{array}{c}0.5 \% \\
\text { Mo+Zeolite }\end{array}$ & 1,900 & 3.2946 & 2.844 & 1.084 & 1.838 & 51.59 \\
\hline $\begin{array}{c}1.0 \% \\
\text { Mo+Zeolite }\end{array}$ & 1.900 & 2.7186 & 2.2301 & 1.9225 & 1.5727 & 49.08 \\
\hline $\begin{array}{c}1.5 \% \\
\text { Mo+Zeolite }\end{array}$ & 2.430 & 2.11 & 3.001 & 2.344 & 1.470 & 52.2 \\
\hline $\begin{array}{c}2.0 \% \\
\text { Mo+Zeolite }\end{array}$ & 1.500 & 1.742 & 2.677 & 4.199 & 1.512 & 60.35 \\
\hline $\begin{array}{c}\text { Zeolite } \\
\begin{array}{c}2.0 \% \\
\text { Mo+Zeolite }\end{array}\end{array}$ & 1.400 & 2.121 & 2.908 & 2.48 & 1.369 & 52.58 \\
\hline
\end{tabular}

CONCLUSION

The conducted researches showed that improvement of technology of carrying out the process and use of the corresponding catalysts allows to reduce to a minimum of loss and to produce high-quality fuel distillates from waste carbon - and hydrogenous raw materials. For the first time, the natural heylanditeclinoptilolite Tayzhuzgen, modified by Mo(VI), subjected to acid-free activation and calcination, was used as a catalyst for the process of hydrogenation processing of waste rubber products at low pressures (up to $5 \mathrm{MPa}$ ). The Physico-chemical characteristics of catalysts were determined. Over Mo(VI)/zeolite catalyst the highest yield of the gasoline and diesel fractions was observed at a concentration of Mo (VI) equal to $0.5 \%$ and the total yield of liquid distillate was equal to $34.59 \%$ by wt.

\section{REFERENCES}

1. A.K. Panda, R.K. Singh and D.K. Mishra, Renewable and Sustainable Energy Reviews, 14, 233(2010), DOI: 10.1016/j.rser.2009.07.005

2. Y. Xue, 2017, Thermochemical conversion of organic and plastic waste materials through pyrolysis, dissertation, Ames, Iowa, pp.28-44, DOI:10.31274/etd-180810-5871

3. G. Braunegg, R. Bona, F. Schellauf and E. Wallner, Polymer-Plastics Technology and Engineering, 43(6), 1755(2004), DOI:10.1081/ppt-200040090

4. Zh. Tashmukhambetova, Y. Aubakirov, L. Sassykova, K.Burkhanbekov, M. Faizullaeva and N.Zhakirova, Revue Roumaine de Chimie, 63(11), 1001 (2018).

5. Zh. Kh. Tashmukhambetova, N.K. Zhakirova, L.R. Sassykova, K.A. Kadirbekov, Y.A. Aubakirov and A.S. Zhumakanova, Oriental Journal of Chemistry, 33(6), 2803(2017), DOI: 10.13005/ojc/330613

6. M. Sh. Akhmetkaliyeva, L.R. Sassykova, Y.A. Aubakirov, S. Sendilvelan, A.S. Zhumakanova, T.S. Abildin, A.K. Zhussupova and M.B. Amangeldi, News of the National Academy of Sciences of the Republic of Kazakhstan, Series of Geology and Technology Sciences, 429(3), 20-29(2018). 


\section{RASĀYAN J. Chem.}

Vol. 12 | No. 4 |1701 - 1709| October - December | 2019

7. J. M.Arandes, I.Abajo, D.López-Valerio, I.Fernández, M.J.Azkoiti, M.Olazar and J.Bilbao, Industrial \& Engineering Chemistry Research, 36(11), 4523(1997), DOI:10.1021/ie970096e

8. M. Prabhahar, S.Sendilvelan and L.R. Sassykova, Indian J. Environmental Protection, 38, 269(2018).

9. L. R. Sassykova, S. Sendilvelan, K. Bhaskar, A. S. Zhumakanova, Y. A. Aubakirov, T. S. Abildin, Sh. N. Kubekova, Z. T. Mataeva and A. A. Zhakupova, News of the National Academy of Sciences of the Republic of Kazakhstan, Series of Geology and Technology Sciences, 434 (2), 181(2019), DOI: 10.32014/2019.2518-170X.53

10. D. Almeida and M. de F. Marques, 2017, Thermal and Catalytic Pyrolysis of Plastic Waste, Chapter 8, in: Thermochemical Waste Treatment, Edit. Elena Cristina Rada, p.133, DOI:10.1201/b19983-12

11. J.F. Mastral, C. Berrueco and J. Ceamanos, Journal of Analytical and Applied Pyrolysis, 80, 427(2007), DOI:10.1016/j.jaap.2006.07.009

12. D.A. Sharuddin, F.Abnisa, W.M.A.W. Daud and M.K.Aroua, Energy Conversion and Management, 115, 308 (2016), DOI:10.1016/j.enconman.2016.02.037

13. S. J. Miller, N. Shah and G. P. Huffman, 2006, Production of Premium Oil Products from Waste Plastic by Pyrolysis and Hydroprocessing, Chapter in: Feedstock Recycling and Pyrolysis of Waste Plastics on, p.345, DOI:10.1002/0470021543.ch13

14. Alexis Baltazar y Jimenez, Progress in Rubber, Plastics and Recycling Technology, 19(2), 117(2003), DOI: $10.1177 / 147776060301900204$

15. F. Shafizadeh, Journal of Analytical and Applied Pyrolysis, 3, 283(1982), DOI:10.1016/01652370(82)80017-x

16. G.W. Huber, S. Iborra and A. Corma, Chemical Reviews, 106, 4044(2006), DOI:10.1021/cr068360d

17. M.S. Mulgaonkar,Fuel and Energy Abstracts, 37(3),202(1996), DOI:10.1016/0140-6701(96)88824-2

18. P. V. Tekade, N. P. Mohabansi and V.B. Patil, Rasayan J. Chem., 4(2), 461(2011).

19. W.B. Ding, W. Tuntawiroon, J. Liang and L.L. Anderson, Fuel Processing Technology, 49(1-3), 49(1996), DOI:10.1016/s0378-3820(96)01024-7

20. D.A.Baiseitov, M.I.Tulepov, L.R. Sassykova, Sh.E. Gabdrashova, A.N.Magazova, O.Dalelkhanuly, Zh.B.Kudyarova and Z.A.Mansurov, Bulgarian Chemical Communications, 49(3), 600(2017).

21. D. Baiseitov, M. Tulepov, L.Sassykova, Sh.Gabdrashova, K.Kudaibergenov and Z.Mansurov, Revue Roumaine de Chimie, 62(3), 249(2017).

22. F. Ateş, N. Miskolczi and N. Borsodi, Bioresource Technology, 133, 443(2013), DOI: 10.1016/j.biortech.2013.01.112

23. L.R. Sassykova, Chemical and Biochemical Engineering Quarterly, 31(4), 447(2017), DOI: $10.15255 /$ cabeq.2016.959

24. L. Sassykova and Y. Aubakirov, Chiang Mai J. Sci., 45(1), 474 (2018).

25. T. Malkow, Waste Management, 24, 53 (2004), DOI:10.1016/s0956-053x(03)00038-2

26. T.P. Vispute, H. Zhang, A. Sanna, R. Xiao and G.W. Huber, Science (New York, N.Y.), 330, 1222 (2010), DOI: $10.1126 /$ science. 1194218

27. L. Sassykova, V. Bunin, A. Nalibayeva and M. Nurakhmetova, Journal of Chemical Technology and Metallurgy, 53(3), 537(2018).

28. F. Zannikos, S. Kalligeros, G. Anastopoulos and E. Lois, J. Renew. Energy, 2013, 1(2013), DOI: $10.1155 / 2013 / 360368$

29. J.M. Heikkinen, J.C. Hordijk, W.de Jong and H. Spliethoff, J. Anal. Appl. Pyrol., 71, 883(2004), DOI:10.1016/j.jaap.2003.12.001.

30. I. Ahmad, M. Ismail Khan, M. Ishaq, H. Khan, K. Gul and W. Ahmad, Polym Degrad Stab, 98, 2512(2013), DOI:10.1016/j.polymdegradstab.2013.09.009

31. K. Burkhanbekov, Y. Aubakirov, Z.Tashmukhametova and T. Abildin, Journal of Material Cycles and Waste Management, 21(3), 633(2019), DOI:10.1007/s10163-018-00825-x

32. Zh. Tashmukhambetova, Y. Aubakirov, Zh. Shomanova, K. Burkhanbekov, R. Safarov, L. Sassykova, N. Zhakirova and M. Faizullaeva, Oriental Journal of Chemistry, 33(6), 2884(2017), DOI:10.13005/ojc/330622 
RASĀYAN J. Chem.

Vol. 12 | No. 4 |1701 - 1709| October - December | 2019

33. Zh. Kh. Tashmukhambetova, Zh. K. Kairbekov, E. A. Aubakirov, K. E. Burkhanbekov, M. F. Faizullaeva and Zh. K. Shomanova, Solid Fuel Chemistry, 50(4), 220(2016), DOI:10.3103/s0361521916040091

34. Z. Feng, J. Zhao, J. Rockwell, D. Baily and G.Huffman, Fuel Processing Technology, 49(1-3), 17(1996), DOI:10.1016/s0378-3820(96)01036-3

35. W.W. Graessley, Advances in Polymer Science, 47(1982), DOI:10.1007/bfb0038532

36. M. Tulepov, Z. Mansurov, L. Sassykova, D. Baiseitov, O. Dalelhanuly, Zh. Ualiev, Sh. Gabdrashova and Zh. Kudyarova, Journal of Chemical Technology and Metallurgy, 54(3), 531(2019).

37. P. O'Connor, Chapter 15 Catalytic Cracking: The Future of an Evolving Process, Studies in Surface Science and Catalysis, 166, 227(2007).

38. G. D. Zakumbaeva, L. B. Shapovalova, B. T. Tuktin and A.A. Omarova, Petroleum Chemistry, 50(2), 135(2010), DOI:10.1134/s096554411002009x

39. Y. Tanimoto, H. Tanaka, Y. Fujiwara and M. Fujiwara, J. Phys. Chem. A, 102 (28), 5611(1998), DOI: $10.1021 /$ jp980261j

40. B.T. Tuktin, A.S. Tenizbayeva, A.A. Omarova, L.R. Sassykova and Zh.A. Sailau, Rasayan Journal of Chemistry, 12(3), (2019).

41. V. S. Yemelyanova, B. T. Dossumova, T. V. Shakiyeva, L.R. Sassykova and S. Sendilvelan, International Journal of Mechanical and Production Engineering Research and Development, 9(4), 1079-1086(2019), DOI:10.24247/ijmperdaug2019111

42. I. Amghizar, L. A. Vandewalle and K. M. Van Geem, Engineering, 3(2), 171 (2017), DOI: 10.1016/J.ENG.2017.02.006

43. D.A. Baiseitov, Sh.E. Gabdrashova, A.K. Akylbai, O. Dalelkhanuly, Zh.B. Kudyarova, L.R. Sassykova, M.I. Tulepov and Z.A. Mansurov, Int. J. Chem. Sci., 14(1), 261(2016).

44. H. Itoh, C. V. Hidalgo, T. Hattori, M. Niwa and Y. Murakami, Journal of Catalysis, 85(2), 521 (1984), DOI:10.1016/0021-9517(84)90241-0

45. R. Khan, I. Ahmad, H. Khan, M. Ismail, K. Gul, A. Yasin and W. Ahmad, Journal of Analytical and Applied Pyrolysis, 120, 493 (2016), DOI:10.1016/j.jaap.2016.06.022

46. L. Sassykova, S. Sendilvelan, M. Telbayeva, K. Dossumov and K. Bhaskar, Journal of Chemical Technology \& Metallurgy, 54(3), 539-546(2019).

47. L. R. Sassykova, S. Sendilvelan, Y. A. Aubakirov, Zh. Kh. Tashmukhambetova, A. A. Batyrbayeva, R. N. Azhigulova, Sh. N. Kubekova, K. O. Sharipov, R. G. Ryskaliyeva, B. B. Tyussyupova and M. A. Sarybayev, News of the National Academy of Sciences of the Republic of Kazakhstan, Series of geology and technology sciences, 436(4), 12(2019), DOI:10.32014/2019.2518-170X.93

[RJC-5435/2019] 